\title{
Economic Policy Uncertainty and the Co-Movement between REITs and Exchange Rate
}

\author{
IBRAHIM D. RAHEEM \\ University of East Anglia * \\ ISMAIL O. FASANYA \\ University of the Witwatersrand
AGBOOLA H. YUSUF
University of Ilorin

\begin{abstract}
The REITs market has attracted a lot of interest among the academic, policymakers, and market participants. The linkages between REITs and macroeconomic and financial variables have been adequately explored in the literature, with more emphasis on linear models. This study expands the frontier of knowledge by examining the role of uncertainty in the comovement/spillover between REITs and the currency markets. Some interesting results were observed. First, using the Diebold and Yilmaz (2012) spillover test, we find that there is strong connectedness between the REITs and currency markets. Second, the BDS test shows that nonlinearity is a very crucial factor to be put into consideration when examining the role of EPU in affecting the interactions between REITs and exchange rate markets. Third, the non-parametric causality-in-quantile test confirms that the connectedness between the markets and EPU is stronger around the lower and middle quantiles. These results have important policy implications for policymakers and market participants. The study also offers suggestions for future research.
\end{abstract}

Keywords: Keywords: REITs, EPU, Nonlinearity, and Causality-in-quantiles

JEL Classifications: F3, G12

${ }^{*}$ Raheem: School of Economics, University of East Anglia, Norwich, UK. E-mail: i.raheem@uea.ac.uk. Fasanya: School of Economics and Finance, University of the Witwatersrand, South Africa. E-mail: ismail.fasanya@wits.ac.za. Yusuf: Department of Economics, University of Ilorin, Nigeria. Email: agboolayusuf2007@gmail.com

(C) 2022 Ibrahim D. Raheem, Ismail O. Fasanya and Agboola H. Yusuf. Licensed under the Creative

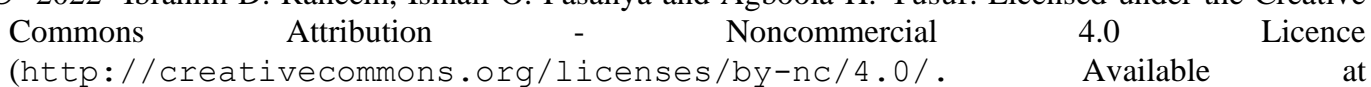
http://rofea.org. 


\section{Introduction}

The sudden interest in issues relating to Real Estate Investment Trusts (REITs) can be justified on three grounds: (i) the surge in pricing dynamics (Marfatia et al., 2017); (ii) the attendant effects of the 2007/2008 global financial crisis (Coen and Lecomte, 2014; Devaney, 2012; Gerlach et al., 2014); and (iii) REITs being a viable source of portfolio diversification (Schindier et al., 2011; and Liow and Newell, 2016). The turn of the millennium has seen tremendous growth in the pricing dynamics of REITs, reaching a market capitalisation of over $\$ 1.3$ trillion, as of July $2020^{1}$. Understandably, this has awakened interest among policymakers and investors. An overview of the literature shows that existing studies could be categorised into two strands: (i) determinants of REITs and; (ii) the contagion between REITs and other financial assets. The literature on the determinants of REITs have used various explanatory variables, including but not limited to inflation, monetary (expected and unexpected) policies, future fund rates and exchange rate, non-REITs financial markets, among others ( $\mathrm{Li}$ and Lie, 2011; Yong and Singh, 2015; Akimov et al., 2015; Ngo, 2017).

This study explores the linkage between REITs and the exchange rate market. Our decision to choose Forex over other competing financial markets (e.g. commodity, bonds, and equity) is explained below. First, we hypothesise that the explanatory power of the exchange rate in the REITs' models cannot be overemphasised, as the relationship between REITs and the rest of the financial markets requires a common source of measurement. Thus, the linkage between REITs and other financial markets would still pass through the exchange rate markets. Second, Ngo (2017) argued that fluctuations in exchange rate movements have more effects in the REITs market, through retail shopping, and real estate sector revenues, tourism (lodging and resorts). Third, the contagion literature has hypothesised that the increasing rate of financial integration and globalisation has increased the degree of connectedness between a domestic economy and the international financial markets (Chang and Chen, 2014; Gorea and Radev, 2014; Morales and Andreosso-O'Callaghan, 2014; Chang and Chen, 2016). A high degree of connectedness in the global financial markets fuels spillover effects. Several studies have examined the spillover dynamics between different asset classes. The initial emphasis was laid on traditional assets (Lee et al., 2012; Nazlioglu et al., 2016). Empirical evidence has suggested that there are fewer benefits of diversification between these markets (Schindler, 2011; Cheok et al., 2011). In response to this, REITs have been inducted into the family of financial assets.

The linkage between financial assets and the exchange rates has been examined using various channels. The supply-demand channel relates to asset price fluctuations, which will exert inflationary pressures and the subsequent changes in exchange rates (Darby, 1982). Other channels are a balance of payment theory (Golub, 1983); monetary channel (Poole, 1970)

\footnotetext{
${ }^{1}$ The market capitalization in 2000 was $\$ 188$ billion. Thus, market capitalization has increased by over $590 \%$ within the space of two decades.
} 
RAHEEM, FASANYA, YUSUF Co-Movement between REITs and Exchange Rate

international trade (Amano and Van Norden, 1998). In this study, we propose that the role of uncertainty is another channel of linkage between REITs and exchange rates. Uncertainty about government policies will enhance the volatility interaction across different financial markets, via changes in the risk preference of investors or changes in global liquidity conditions (Albulescu et al., 2020). The capital-intensive nature of both the currency and REITs markets explains the high patronage of hedging and speculating services globally. It could be hypothesised that U.S. policies play significant roles in the risk transmissions across these markets. Hence, investors will respond to changes in liquidity conditions and policy decisions that affect global appetite.

No doubt, a huge number of studies have delved into uncertainty, REITs, and exchange rates using various approaches and settings (Ertugrul et al., 2008; Ngo, 2017). However, little or nothing is known about how uncertainty affects the interaction between different assets classes (as in REITs and exchange rate, as used in this study). Given that uncertainty about government policies will affect the value of the currency relative to trading partners, it is expected that both REITs and currency markets will have high exposures concerning policy shocks. Thus, there is the need to analyse the spillover models. We hypothesise how the role of economic policy uncertainty (EPU) of the U.S will affect the spillover between REIT and exchange rate. This said the relationship between the markets and EPU is examined via the prism of the nonlinearity causality test. The choice of the non-linearity test is informed by the extant literature that posits non-normality in the dynamics of REIT and/or housing prices. Non-normality has been measured in different ways: quantile regressions (Hoesli and Reka, 2013; Caporin et al., 2019); contagion effects (Caporin et al., 2019; Chang and Chen, 2014); asymmetry (Tsai and Chiang, 2013), time-varying effects (Marfatia et al., 2017). In supporting the claim of nonlinearity, Chang (2011) concluded that expected and unexpected monetary policies have a different impact on REITs' return and markets conditions. Admittedly, it is practically impossible to simultaneously account for these various measures of non-linearity. Hence, we test for the role of quantile effects. In essence, we assume the relationship between EPU and the comovement between REITs and currency is dynamic along quantiles. Previous studies have examined the dynamics of REITs along with market conditions. For instance, Lee et al. (2014) concluded that the prices of REITs are quantile dependent. Albulescu et al. (2020) argued that financial series, REITs inclusive, exhibit heterogeneity, which can be captured by quantile-based methods. This approach will uncover the relationship between the variables of interest along the tail region of the conditional distribution.

Based on the foregoing, the objective of this study is to examine the role of EPU in the comovement/spillover between REITs and currency markets. This objective is achieved in two phases. The first stage relates to the use of Diebold and Yilmaz's (2012) spillover effect to examine the connectedness between the REITs and currency markets. The second stage uses the non-parametric causality-in-quantile test between spillover results and EPU. The causality- 
in-quantile test is useful in tracing the unconditional distribution in the REITs-currency markets on the conditional distribution of EPU. We make the following contributions to the literature. First, studies have hitherto focused on the U.S. REITs market. In addition, the co-movement between stocks and other assets has been analysed. However, we consider the spillover between REITs and currency markets drawing data from the US and 14 other developed REITs markets. Second, we examine the potential channel of linkage between REITs and currency, by considering the role of EPU. As such, this is the first study that goes beyond examining the spillover between these markets.

Foreshadowing our results, we found that: (i) there is strong connectedness between the REITs and currency markets; (ii) nonlinearity is a crucial factor to be considered when examining the role of EPU in affecting the interactions between REITs and exchange rate markets; (iii) the connectedness among these markets are primarily driven by EPU. The rest of the article is structured as follows. Data and methodology are presented in section 2. Empirical results are discussed in Section 3 and Section 4 houses the conclusion and policy implications/recommendations.

\subsection{Methodology and Data}

\subsection{The Diebold - Yilmaz Spillover Approach}

This first phase of the analysis considers the Diebold and Yilmaz (2012, hereinafter DY) approach to determine the co-movement between REITs and exchange rate. The DY spillover approach operates through a generalised vector autoregressive (VAR) model of KPSS where variables are invariant in the ordering process. Specifically, the DY results generate four different spillover indexes which include Total Spillovers, Directional Spillovers, Net Spillovers, and Net Pairwise Spillovers. These indexes are set up through a covariance stationary $\operatorname{VAR}(\rho)$ as:

$$
r_{t}=\sum_{i=1}^{p} \phi_{i} r_{t-i}+\varepsilon_{t} ; \varepsilon_{t} \sim\left(0, \sum\right)
$$

where $\varepsilon_{t}$ follows a vector of independently and identically distributed disturbances and $\sum$ is the variance matrix for the error vector $\varepsilon$. Equation (1) can be re-specified in a moving average process as:

$$
r_{t}=\sum_{i=0}^{\infty} A_{i} \varepsilon_{t-i}
$$

where $A_{i}$ is assumed to obey the recursion $A_{i}=\Phi_{1} A_{i-1}+\Phi_{2} A_{i-2}+\ldots+\Phi_{p} A_{i-p} . A_{0}$ is an identity matrix with a $N \times N$ dimension and $A_{i}=0$ for $i<0$. We derive the variance decompositions that are necessary for determining the various set of indexes as expressed in 
RAHEEM, FASANYA, YUSUF Co-Movement between REITs and Exchange Rate

equation (2). We provide some preliminary explanations that are relevant before characterising different representations for the set of spillover indexes.

1. Own variance shares are defined as the fractions of the $\mathrm{H}$-step-ahead error variances in forecasting $r_{i}$ that are due to shocks to $r_{i}$, for $i=1,2 \ldots N$.

2. Cross variance shares or spillovers are defined as the fractions of the H-step ahead error variances in forecasting $r_{i}$ that are due to shocks to $r_{j}$, for $i, j=1,2, \ldots, N$ such that $i \neq j$.

3. Based on the generalised VAR framework of KPPS, $H$-step-ahead forecast error variance decompositions denoted by $\theta_{i j}^{g}$ is written as:

$$
\theta_{i j}^{g}(H)=\frac{\sigma_{j j}^{-1} \sum_{h=0}^{H-1}\left(e_{i}^{\prime} A_{h} \sum e_{j}\right)^{2}}{\sum_{h=0}^{H-1}\left(e_{i}^{\prime} A_{h} \sum A_{h}^{\prime} e_{i}\right)}
$$

where $\sigma_{j j}$ is the standard deviation of $\varepsilon$ for the $j t h$ equation and $e_{i}$ is the selection vector, with one as the ith element and zeros otherwise.

Since the sum of the contributions to the variance of the forecast error is not equal to one that is $\sum_{j=i}^{N} \theta_{i j}^{g}(H) \neq 1$; DY (2012) normalised each entry of the variance decomposition matrix by the row sum to use the full information of the matrix. The normalised KPPS $H$-stepahead forecast error variance decompositions represented by $\tilde{\theta}_{i j}^{g}(H)$ is expressed as:

$$
\tilde{\theta}_{i j}^{g}(H)=\frac{\theta_{i j}^{g}(H)}{\sum_{j=1}^{N} \theta_{i j}^{g}(N)}
$$

where $\sum_{j=1}^{N} \tilde{\theta}_{i j}^{g}(H)=1$ and $\sum_{1, j=1}^{N} \tilde{\theta}_{i j}^{g}(H)=N$ by construction.

Following the above set of preliminaries, we derive the total spillover index as:

$$
S^{g}(H)=\frac{\sum_{\substack{i, j=1 \\ i \neq j}}^{N} \widetilde{\theta}_{i j}^{g}(H)}{\sum_{1, j=1}^{N} \widetilde{\theta}_{i j}^{g}(H)} \times 100=\frac{\sum_{\substack{i, j=1 \\ i \neq j}}^{N} \widetilde{\theta}_{i j}^{g}(H)}{N} \times 100
$$

The contribution of spillovers of volatility shocks across these classes of assets is captured in equation (5) with all parameters previously defined. Essentially, we capture the total spillover index as the share of asset volatility shocks across the fourteen (14) countries REITs-FX markets to the total forecast error variance.

To quantify the spillover route across the entire markets using the DY (2012) approach, we consider two sets of directional spillovers which are 'Directional Spillover To' and 'Directional Spillover From'. The return or volatility received by market $i$ from all other markets $j$ is measured through the 'Directional Spillover From' while the return or volatility transmission 
by market $i$ to all other markets $j$ is analysed by the 'Directional Spillover To'. The computation of 'Directional Spillover To' index defined by $S_{. i}^{g}$ is given as:

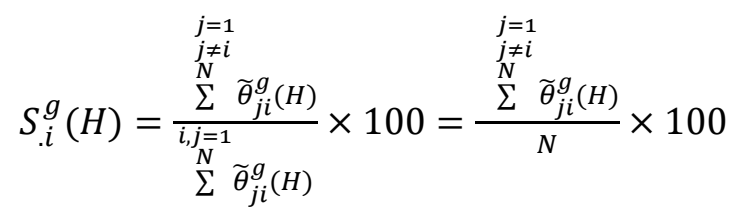

while the computation of the 'Directional Spillover From' index defined as $S_{i .}^{g}$ is measured as:

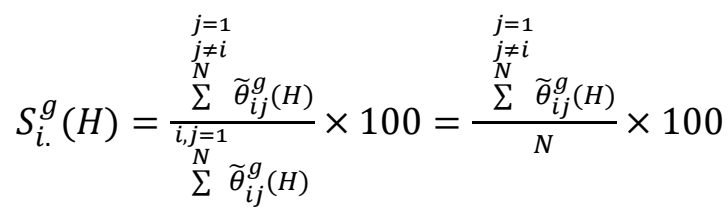

Correspondingly, we obtain the Net Spillovers following the index specified below:

$$
S_{i}^{g}(H)=S_{. i}^{g}(H)-S_{i .}^{g}(H)
$$

The difference between the Directional Spillover To' index and 'Directional Spillover From' index is known as the net spillovers which is defined in Equation (8). In essence, the net spillovers characterises information about each market's contribution to the return/volatility of other markets.

In examining the net pairwise volatility spillover between markets $i$ and $j$, we determine the variation between the gross volatility shocks transmitted from market $i$ to market $j$ and those transmitted from $j$ to $i$ :

$$
S_{i j}^{g}(H)=\left[\begin{array}{cc}
\frac{\widetilde{\theta}_{j i}^{g}(H)}{i, k=1}-\frac{\widetilde{\theta}_{i j}^{g}(H)}{j, k=1} \\
\sum \widetilde{\theta}_{i k}^{g}(H) & \sum \widetilde{\theta}_{j k}^{g}(H)
\end{array}\right] \times 100=\left[\frac{\widetilde{\theta}_{j i}^{g}(H)-\widetilde{\theta}_{i j}^{g}(H)}{N}\right] \times 100
$$

In our paper, we consider second-order 14-variable VARs with 10-step-ahead forecasts.

\subsection{Nonlinear Causality test}

We adopt the Balcilar et al. (2018a) framework that is important for uncovering nonlinearity through the methodology of Nishiayama et al. (2011) and Jeong et al. (2012). As noted by Jeong et al. (2012), the variable $x_{t}$ (EPU) does not cause $y_{t}$ (market spillovers - total and net) in the $\sigma-q u a n t i l e$ with respect to the lag-vector of $\left\{y_{t-1}, \ldots, y_{t-q}, x_{t-1}, x_{t-q}\right\}$ if

$$
Q_{\sigma}\left(y_{t-1}, \ldots, y_{t-q}, x_{t-1}, \ldots, x_{t-q}\right)=Q_{\sigma}\left(y_{t-1}, \ldots, y_{t-q}\right)
$$


RAHEEM, FASANYA, YUSUF Co-Movement between REITs and Exchange Rate

While $x_{t}$ causes $y_{t}$ in the $\sigma$ th quantile with respect to $\left\{y_{t-1}, \ldots, y_{t-q}, x_{t-1}, x_{t-q}\right\}$ if

$$
Q_{\sigma}\left(y_{t-1}, \ldots, y_{t-q}, x_{t-1}, x_{t-q}\right) \neq Q_{\sigma}\left(y_{t-1}, \ldots, y_{t-q}\right)
$$

Definitively, $Q_{\sigma}(\cdot)=\sigma$ th quantile of $y_{t}$ depending on $t$ and $0<\sigma<1$. We denote $V_{t-1} \equiv$ $\left(y_{t-1}, \ldots, y_{t-q}\right), U_{t-1} \equiv\left(x_{t-1}, \ldots, x_{t-q}\right)$, and $W_{t}=\left(U_{t}, V_{t}\right)$; and $F_{y_{t} \mid W_{t-1}}\left(y_{t} \mid W_{t-1}\right)$ and $F_{y_{t} \mid V_{t-1}}\left(y_{t} \mid V_{t-1}\right)$ represents the conditional distribution of $y_{t}$ given $W_{t-1}$ and $V_{t-1}$, respectively. Also, $F_{y_{t} \mid V_{t-1}}\left(y_{t} \mid V_{t-1}\right)$ is assumed to be continuous in $y_{t}$ for almost all $W_{t-1}$. If we proceed by denoting $Q_{\sigma}\left(W_{t-1}\right) \equiv Q_{\sigma}\left(W_{t-1}\right)$ and $Q_{\sigma}\left(V_{t-1}\right) \equiv$ $Q_{\sigma}\left(V_{t-1}\right)$, then we have $F_{y_{t} \mid W_{t-1}}\left\{Q_{\sigma}\left(W_{t-1}\right)\right\}=\sigma$ with a probability of one. Followingly, the hypothesis to be tested based on the specified definitions in equations (10) and (11) are

$$
\begin{aligned}
& H_{0}=P\left\{F_{y_{t} \mid W_{t-1}}\left\{Q_{\sigma}\left(W_{t-1}\right)\right\}=\sigma\right\}=1 \\
& H_{1}=P\left\{F_{y_{t} \mid W_{t-1}}\left\{Q_{\sigma}\left(W_{t-1}\right)\right\}=\sigma\right\}<1
\end{aligned}
$$

Furthermore, Jeong et al. (2012) utilise the distance measure $\left.J=\left\{W_{t-1}\right) f_{W}\left(W_{t-1}\right)\right\}$, where $\tau_{t}$ and $f_{z}\left(W_{t-1}\right)$ are the regression error and marginal density function of $Z_{t-1}$, respectively. The regression error emanates through its basis in the null hypothesis as specified in equation (12), which can only be true if and only if $E\left[1\left\{W_{t-1}\right)\right\}=\sigma$ or, equivalently, $1\left\{y_{t} \leq Q_{\sigma}\left(V_{t-1}\right)\right\}=$ $\sigma+\tau_{t}$, where $1\{\cdot\}$ is the indicator function. Thus, Jeong et al. (2012) specify the distance measure, $G \geq 0$, as follows:

$$
G=E\left[\left\{F_{y_{t} \mid W_{t-1}}\left\{Q_{\sigma}\left(W_{t-1}\right)\right\}-\sigma\right\}^{2} f_{W}\left(W_{t-1}\right)\right]
$$

It is pertinent to note that we will have a situation where $G=0$ if and only if the null in equation (12) is true, while we will have $G>0$ under the alternative hypothesis in equation (13). Also, Jeong et al. (2012) introduced a feasible kernel-based test statistic for J which has the following form:

$$
\widehat{G}_{T}=\frac{1}{T(T-1) s^{2 q}} \sum_{t=q+1}^{T} \sum_{r=q+1, r \neq t}^{T} K\left(\frac{W_{t-1}-Z_{s-1}}{s}\right) \widehat{\tau}_{t} \widehat{\tau}_{s}
$$

where $K(\cdot)$ denotes the kernel function with bandwith $s . \mathrm{T}, \mathrm{q}, \widehat{\tau_{t}}$ is the sample size, lag-order, and estimate of the regression error, respectively. The estimate of the regression error is computed thus:

$$
\widehat{\tau_{t}}=1\left\{y_{t} \leq \widehat{Q_{\sigma}}\left(Y_{t-1}\right)\right\}-\sigma
$$


Also, we further use the nonparametric kernel method to estimate the $\sigma t h$ conditional quantile of $y_{t}$ given $V_{t-1}$ as $\hat{Q}_{\sigma}\left(V_{t-1}\right)=\hat{F}_{y_{t} \mid V_{t-1}}^{-1}\left(V_{t-1}\right)$, where the Nadarya-Watson Kernel estimator is specified as follows

$$
\hat{F}_{y_{t} \mid V_{t-1}}\left(y_{t} \mid V_{t-1}\right)=\frac{\sum_{r=q+1, r \neq t}^{T} N\left(\frac{V_{t-1}-V_{r-1}}{S}\right) 1\left(y_{r} \leq y_{t}\right)}{\sum_{r=q+1, r \neq t}^{T} N\left(\frac{V_{t-1}-V_{r-1}}{S}\right)}
$$

where $N(\cdot)$ is the kernel function and $s$ is the bandwidth.

Balcilar et al. (2018a) extend the framework of Jeong et al. (2012) by developing a test for the second moment. Thus, they adopt the nonparametric Granger-quantile-causality approach by Nishiyama et al. (2011). To illustrate the causality in a higher-order moment, we assume

$$
y_{t}=h\left(V_{t-1}\right)+\vartheta\left(U_{t-1}\right) \tau_{t}
$$

where $\tau_{t}$ is the white noise process and $h(\cdot)$ and $\vartheta(\cdot)$ equals the unknown functions that satisfy pertinent conditions for stationarity. Although, this specification allows not granger-type causality testing from $U_{t-1}$ to $y_{t}$, however, it could detect the "predictive power" from $U_{t-1}$ to $y_{t}^{2}$ when $\vartheta(\cdot)$ is a general nonlinear function. Thus, we re-formulate equation (18) to account for the null and alternative hypothesis for causality in variance to equations 19 and 20 , respectively.

$$
\begin{aligned}
& H_{0}=P\left\{F_{y_{t}^{2} \mid W_{t-1}}\left\{Q_{\sigma}\left(W_{t-1}\right)\right\}=\sigma\right\}=1, \\
& H_{1}=P\left\{F_{y_{t}^{2} \mid W_{t-1}}\left\{Q_{\sigma}\left(W_{t-1}\right)\right\}=\sigma\right\}<1,
\end{aligned}
$$

We obtain the feasible test statistic for the testing of the null hypothesis in equation (19) and then replace $y_{t}$ in equations (15) - (17) with $y_{t}^{2}$ (that is, volatility). With the inclusion of Jeong et al.'s (2012) approach, we overcame the issue that causality in mean implies causality in variance. Specifically, we interpret the causality in higher-order moments through the use of the following model:

$$
y_{t}=h\left(U_{t-1}, V_{t-1}\right)+\tau_{t}
$$

Thus, we specify the higher-order quantile causality as

$$
\begin{aligned}
& H_{0}=P\left\{F_{y_{t}^{k} \mid W_{t-1}}\left\{Q_{\sigma}\left(W_{t-1}\right)\right\}=\sigma\right\}=1, \quad \text { for } k=1,2, \ldots, k, \\
& H_{1}=P\left\{F_{y_{t}^{k} \mid W_{t-1}}\left\{Q_{\sigma}\left(W_{t-1}\right)\right\}=\sigma\right\}<1, \quad \text { for } k=1,2, \ldots, k .
\end{aligned}
$$


RAHEEM, FASANYA, YUSUF Co-Movement between REITs and Exchange Rate

Overall, we test that $x_{t}$ granger causes $y_{t}$ in $\sigma$ th quantile up to the $\mathrm{K}$-th moment through the use of equation (22) to construct the test statistic of equation (15) for each k. Although, Nishiyama et al. (2011) note that it is not easy to combine different statistics for each $k=$ $1,2, \ldots, k$ into one statistic for the joint null in equation (22) which is mutually correlated. However, to circumvent this, we adopt a sequential-testing method described by Nishiyama et al. (2011) with some modifications. To begin with, we test for the nonparametric granger causality in mean $(\mathrm{k}=1)$. Failure to reject the null of $\mathrm{k}=1$ does not translate into non-causality in variance, thus, we construct the tests for $\mathrm{k}=2$. Finally, we test for the existence of causalityin-mean and variance successively. We determine the lag order using SIC. The bandwidth is selected through the use of the least-squares cross-validation method. For $K(\cdot)$ and $L(\cdot)$, we utilize the Gaussian kernels.

\subsection{Data and Results}

\subsection{Data Description}

The empirical analyses utilise monthly data of REITs indices and exchange rates of 14 countries (Australia, Belgium, Canada, France, Germany, Hong Kong, Japan, Malaysia, Netherlands, New Zealand, Singapore, South Africa, Turkey, and the United Kingdom) and the US EPU index. The start and end dates are governed based on the data availability of the US EPU index. The REITs and exchange rate data are sourced from the DataStream database of Thomson Reuters, with the real estate data corresponding to the S\&P REITs indices for each country. The exchange rate is defined as the number of local currency units to one USD. For the proxy of the EPU, we select the US EPU index constructed by Baker, Bloom, and Davis (2016) which are available for download from Baker's website, http://www.policyuncertainty.com.

To measure the economic policy uncertainty of the US, Baker et al., (2016) construct an index from three types of underlying components. The first component weighs newspaper coverage of policy-related economic uncertainty. In this component, an index search of 10 large newspapers is used to construct a normalized index of news articles that characterize policyrelated economic uncertainty. In the second component, the index draws on reports by the Congressional Budget Office (CBO) that compile lists of temporary federal tax code provisions where an annual dollar-weighted of tax code provisions schedule that is meant to expire in the next ten years is created to construct the stability in and certainty about the tax code. The third component uses disagreement among economic forecasters as a proxy for the uncertainty that is drawn on the Federal Reserve Bank of Philadelphia's Survey of Professional Forecasters. Under this component, the dispersion among the three forecast variables that are directly influenced by government policy (CPI, Federal spending; and State and Local spending) are 
used as indices of uncertainty about policy-related macroeconomic variables. The overall index is now constructed by normalizing each of these three components by their standard deviation before January 2012 after which weights (1/2 for the first component; and 1/6 on each of the other components) are attached to each component to compute their average values.

For the basic conditions of stationarity of the variables required for our nonlinear causality to hold, we decided to work with logarithmic returns series of both REITs and exchange rates (monthly natural logarithmic change expressed in percentages) since both series returns were non-stationary following the standard unit root tests2. As for the EPU, we work with the logarithmic levels of the EPU index which is found to be stationary following the standard unit root tests.3 Following the descriptive analysis in Table 1, it is not surprising that the JarqueBera test rejects the null hypothesis of normal distribution for all the series from the reports of both the skewness and kurtosis statistics. While the skewness values hover between positive and negative for all the returns series, their kurtosis estimates exceed the standard threshold. This suggests the presence of extreme fluctuations in these REITs and currency markets. The non-normality of the series gives a relative indication of heavy right or left tail and excess kurtosis. This could further suggest the presence of nonlinearity along the time paths of the series such that the use of linear or constant parameter models would bring about spurious results. This gives a concrete justification for our choice of quantiles-based causality test. In addition, the evidence of heavy tails, as well as high volatility passes, motivate the necessity to examine the relationship in both the conditional-mean and conditional-variance (see Balcilar et al., 2015).

\subsection{Analysis of Spillover effects}

In examining the connection between REITs and exchange rates pairs of countries under study, Table 2 reports the spillover results based on what DY defined as the contribution to the variance of the 100-day forecast errors of one asset from innovations to another asset. The DY approach is usually partitioned into two: the Spillover Tables and the Rolling Window Analyses ${ }^{4}$. The former produces a single-fixed (scalar) value for each of the indices for interest.

2 The full details of the preliminary analysis are available on request from the authors.

3 These results contradict the theoretical argument of measures of uncertainty which are meant to be stationary. However, the statistical results presented here deviate from this which may be as a result of the sample frame used in this study. The full preliminary results are available on request from the authors.

${ }^{4}$ The essence of the rolling window analyses is to complement the spillover table as it unveils the cyclical and secular movements explaining the behaviour of the spillovers from one period to another. However, in this present study we only focus on the spillover table. 
RAHEEM, FASANYA, YUSUF Co-Movement between REITs and Exchange Rate

This may be useful where the interest is to estimate the aggregate spillovers over a particular time. The spillover table shows the computation of Total Spillover, Directional Spillover, and Net Spillover indexes from one asset to another asset. The net spillover is computed by the difference between the total contributions given by an asset and the total it gives, with a positive value implying that the asset in question is a net transmitter, rather than a net receiver.

Table 1: Summary statistics

\begin{tabular}{|c|c|c|c|c|c|c|c|c|}
\hline & Mean & Max & Min & Std. Dev. & Skew & Kurt & $\mathrm{J}-\mathrm{B}$ & Prob \\
\hline AUS_EXR & 0.0106 & 9.1115 & -6.970 & 0.8305 & 0.6363 & 14.410 & 17865.59 & 0 \\
\hline AUS_REIT & -0.0317 & 10.5033 & -18.482 & 1.8434 & -1.3895 & 16.959 & 27457.67 & 0 \\
\hline BEL_EXR & 0.0082 & 2.9692 & -3.726 & 0.6077 & -0.0484 & 5.596 & 914.4977 & 0 \\
\hline BEL_REIT & 0.0010 & 10.6694 & -14.544 & 1.3438 & -0.6309 & 14.199 & 17214.19 & 0 \\
\hline CAN_EXR & 0.0113 & 3.2982 & -3.770 & 0.5994 & 0.1375 & 6.192 & 1391.403 & 0 \\
\hline CAN_REIT & -0.0095 & 9.9865 & -17.995 & 1.3653 & -1.9865 & 31.134 & 109421.3 & 0 \\
\hline FRA_EXR & 0.0082 & 2.9205 & -3.678 & 0.6077 & -0.0588 & 5.354 & 753.0157 & 0 \\
\hline FRA_REIT & -0.0225 & 15.0591 & -20.777 & 1.7642 & -0.5711 & 15.242 & 20490.3 & 0 \\
\hline GER_EXR & 0.0082 & 2.9205 & -3.678 & 0.6077 & -0.0588 & 5.354 & 753.0157 & 0 \\
\hline GER_REIT & -0.0059 & 27.6478 & -22.542 & 2.3784 & 0.1712 & 20.564 & 41831.49 & 0 \\
\hline HKG_EXR & 0.0000 & 0.2793 & -0.426 & 0.0364 & -1.0320 & 21.475 & 46840.07 & 0 \\
\hline HKG_REIT & 0.0333 & 10.0790 & -13.251 & 1.1688 & -0.5461 & 15.082 & 19945.92 & 0 \\
\hline JPN_EXR & -0.0017 & 6.2034 & -3.768 & 0.6540 & 0.0539 & 9.284 & 5354.582 & 0 \\
\hline JPN_REIT & -0.0042 & 12.9232 & -21.826 & 1.5351 & -0.8628 & 26.608 & 75947.57 & 0 \\
\hline MLY_EXR & 0.0077 & 2.0260 & -3.596 & 0.4260 & -0.3895 & 7.764 & 3136.592 & 0 \\
\hline MLY_REIT & 0.0002 & 9.9757 & -8.860 & 0.9489 & 0.1998 & 13.032 & 13661.99 & 0 \\
\hline NLD_EXR & 0.0001 & 7.5508 & -5.207 & 0.4291 & 1.3929 & 54.912 & 366322.8 & 0 \\
\hline NLD_REIT & -0.0516 & 10.3204 & -16.671 & 1.6914 & -0.6866 & 11.462 & 9961.633 & 0 \\
\hline NZL_EXR & 0.0067 & 6.4159 & -6.353 & 0.8305 & 0.2133 & 7.781 & 3122.365 & 0 \\
\hline NZL_REIT & -0.0062 & 8.9610 & -17.943 & 1.2138 & -1.4182 & 24.782 & 65396.69 & 0 \\
\hline SAF_EXR & 0.0304 & 16.1723 & -6.776 & 1.1182 & 1.1661 & 19.342 & 36935.38 & 0 \\
\hline SAF_REIT & -0.0470 & 14.2610 & -19.249 & 1.8514 & -1.1230 & 18.602 & 33675.51 & 0 \\
\hline SGP_EXR & -0.0011 & 2.6635 & -2.321 & 0.3581 & 0.0448 & 6.905 & 2068.072 & 0 \\
\hline SGP_REIT & -0.0081 & 20.4222 & -17.740 & 1.3385 & 0.1252 & 38.697 & 172726.3 & 0 \\
\hline TRK_EXR & 0.0526 & 14.7563 & -7.997 & 0.9547 & 1.3887 & 26.814 & 77910.33 & 0 \\
\hline TRK_REIT & -0.0748 & 17.1517 & -18.457 & 2.5316 & -0.3613 & 8.688 & 4456.742 & 0 \\
\hline UK_EXR & 0.0153 & 8.4081 & -2.990 & 0.6267 & 1.0131 & 15.594 & 22054.62 & 0 \\
\hline UK_REIT & -0.0261 & 11.7117 & -24.279 & 1.8973 & -1.0253 & 17.510 & 29106.08 & 0 \\
\hline
\end{tabular}

Source: Authors' computation 
In other words, if the net spillover value is positive, then the asset transmits more shocks or information to other assets than it receives from them. A closer look at the spillover results in Table 2 reveals that the REITs of the Netherlands, France, and the United Kingdom are the largest shock receivers from all other assets respectively, while Malaysia, Japan, and Hong Kong's REITs are the least receiver of shocks in the sample. Interestingly, Belgium, Australia, and Canada are the highest transmitters of shocks. The likely reason for the high spillovers of Australia and Belgium could be linked to the significant role they both played in the REITs market in recent times. For instance, Australia and the UK are edging closer to being considered mature markets (the same bracket with only the US), while Belgium has been moved recently to the established REITs group, having classified as emerging REITs.

Examining the spillover effects of the exchange rate volatility across the different REITs markets, it is seen that among the countries' REITs, ten of these countries REITs (France, Germany, Hong Kong, Japan, Malaysia, Netherlands, Singapore, South Africa, Turkey, and the United Kingdom) receive more shocks, making them more susceptible to risk in the exchange rate. Thus, leading to their negative net spillover values as presented in Table 2. Furthermore, the negative net spillover estimates for these countries' REITs indicate that they serve as a net receiver of shocks to the overall exchange rate market. This is consistent with Hsieh and Peterson (2000), Ertugrul et al., (2008), Lin, Rahman, and Yung (2009), Xiao, Lin and Li (2014) and Ngo (2017). Although Ertugrul et al., (2008) suggest minimal evidence of attention of REITs firms to exchange rate risk. These two studies collectively document that about half of the REITs engage in hedging activities. Interest rate derivatives account for $80 \%$, and foreign currency derivatives for a mere $2 \%$ of the derivative use of these firms while Hsieh and Peterson (2000) and Lin, Rahman, and Yung (2009), Ngo (2017) suggest a significant contribution of movement in the exchange rate on the REITs market. This result is contrary to the findings of Kola and Kodongo (2016) that exchange rates and interest rates do not explain developing countries' REITs returns represented by Bulgaria and South Africa, as well as in developed markets, represented by the US. In the case of the other countries, we see that the spillover effects of REITs to exchange rate risk significantly differ across the countries and are stronger (as in the case of Australia, Belgium, Canada, and New Zealand). The implication of this is that they are less sensitive to exchange rate movements. This is corroborated by the findings of Payne (2003) and Kola and Kodongo (2017). While it is not unexpected to see the reaction of Australian REITs to movement in exchange rates shocks, as Australia is edging closer to becoming a mature REITs economy alongside the US, the significant spillover effect from the Belgium REITs could be an indication of the recent developments in the country's REITs of moving from an emerging to a more established REITs. In addition, the positive net spillover 
RAHEEM, FASANYA, YUSUF Co-Movement between REITs and Exchange Rate

estimate for REITs indicates that REITs serve as a net transmitter of shocks to the overall exchange rate market, consistent with Kola and Kodongo (2017).

Concluding this section on volatility spillovers in the REITs and currency markets, it is evident that there is an established transmission of shocks. Although the degree and direction of shocks transmission vary, just like the exchange rate seems to be closely knitted to France, Germany, Hong Kong, Malaysia, Netherlands, Singapore, South Africa, Turkey, and the United Kingdom, and Japan, being a weak receiver of shocks, the overall performance still suggests significant connectedness among the markets. Looking at the total spillover index, the computed value is $43.2 \%$ which is an indication that slightly less than half of the total variance of the forecast errors during the sample is explained by shocks across the REITs-currency pairs, whereas the remaining $53.9 \%$ is explained by idiosyncratic shocks. This proves the level of connections that exist between REITs and exchange rate movements and it is well corroborated in the literature on the likely risks REITs may be exposed to, especially when it comes to the exchange rate volatility (see, Lin, Rahman, and Yung, 2009; Xiao, Lin and Li, 2014; and Ngo, 2017).

Table 2: Diebold and Yilmaz spillover results

\begin{tabular}{|l||c|c|c|c|c|}
\hline \multirow{2}{*}{ REITs $\leftrightarrow$ EXR } & \multicolumn{4}{|c|}{ Total contribution } & \multirow{2}{*}{$\begin{array}{c}\text { Net spillover } \\
\text { (b-a) }\end{array}$} \\
\cline { 2 - 5 } & $\begin{array}{c}\text { From others } \\
(\mathbf{a})\end{array}$ & $\begin{array}{c}\text { To others } \\
(\mathbf{b})\end{array}$ & $\begin{array}{c}\text { To self } \\
(\mathbf{c})\end{array}$ & $\begin{array}{c}\text { Including own } \\
(\mathbf{b + c})\end{array}$ & 225 \\
\hline Australia & 20 & 245 & 79.8 & 324 & 242 \\
\hline Belgium & 24 & 266 & 76.1 & 343 & 120 \\
\hline Canada & 35 & 115 & 64.9 & 179 & -26 \\
\hline France & 66 & 40 & 34.3 & 74 & -32 \\
\hline Germany & 38 & 6 & 62.2 & 69 & -3 \\
\hline Hong Kong & 14 & 11 & 85.6 & 97 & -1 \\
\hline Japan & 16 & 15 & 83.9 & 99 & -6 \\
\hline Malaysia & 12 & 6 & 87.8 & 94 & -72 \\
\hline Netherlands & 78 & 6 & 21.7 & 28 & 1 \\
\hline New Zealand & 41 & 42 & 59.3 & 101 & -37 \\
\hline Singapore & 44 & 7 & 56.0 & 63 & -6 \\
\hline South Africa & 38 & 32 & 62.3 & 94 & -45 \\
\hline Turkey & 29 & 18 & 70.6 & 89 & \\
\hline United & 61 & 16 & 39.0 & 55 & \\
\hline Kingdom & & & & & \\
\hline
\end{tabular}

Source: Authors' computation 
Linking these spillover transmissions to uncertainty in economic policy, the U.S. is an indispensable factor driving the global financial cycle through her various monetary policies pronounced by the Federal Reserves. Thus, the connectedness across the markets may be driven by policy uncertainty having first affected global liquidity and investors' decisions. This implies that uncertainty in economic policy that drives fluctuations in the exchange rate and/or REITs may induce volatility shocks to the other markets. The possibility of economic policy uncertainty to affect the volatility spillover between the currency and REITs markets is therefore the main thrust of this paper and it is the focus in the next section.

\subsection{Causality test results}

Following the observed evidence of volatility interactions between REITs and foreign exchange markets, we proceed to the examination of the causal effect of EPU on the established connectedness in the markets. Doing this requires that we test the null hypothesis that EPU does not cause the overall spillover and the total net spillover for each country-specific REITs and exchange rates under consideration. We initially examine the causal effect from the perspective of linear relationship with the results reported in Table 3. It is observed that the effect of EPU is found to be insignificant in most cases, barring only Australia and Netherlands.

Table 3: Linear causality test results

\begin{tabular}{|l|c|c|}
\hline Null hypothesis & F-statistics & Prob. value \\
\hline \hline EPU does not Granger cause overall spillover & 1.1074 & 0.333 \\
\hline EPU does not Granger cause net spillover for Australia & $3.1846^{* *}$ & 0.044 \\
\hline EPU does not Granger-cause net spillover for Belgium & 1.2718 & 0.283 \\
\hline EPU does not Granger-cause net spillover for Canada & 1.4190 & 0.245 \\
\hline EPU does not Granger-cause net spillover for France & 0.5693 & 0.567 \\
\hline EPU does not Granger-cause net spillover for Germany & 0.3523 & 0.703 \\
\hline EPU does not Granger-cause net spillover for Hong Kong & 1.1827 & 0.309 \\
\hline EPU does not Granger-cause net spillover for Japan & 1.0578 & 0.350 \\
\hline EPU does not Granger-cause net spillover for Malaysia & 1.3900 & 0.252 \\
\hline EPU does not Granger-cause net spillover for the Netherlands & $3.2685^{* *}$ & 0.041 \\
\hline EPU does not Granger-cause net spillover for New Zealand & 2.3232 & 0.101 \\
\hline EPU does not Granger-cause net spillover for Singapore & 0.9139 & 0.403 \\
\hline EPU does not Granger-cause net spillover for South Africa & 2.1631 & 0.118 \\
\hline EPU does not Granger-cause net spillover for Turkey & 0.4933 & 0.611 \\
\hline $\begin{array}{l}\text { EPU does not Granger-cause net spillover for the United } \\
\text { Kingdom }\end{array}$ & 0.0859 & 0.917 \\
\hline
\end{tabular}

Source: authors' computation. ** denotes significance at 5\% critical level. 


\section{RAHEEM, FASANYA, YUSUF Co-Movement between REITs and Exchange Rate}

However, we observe that this weak performance of the policy-based uncertainty affecting the connectedness in the markets is due to the likely presence of nonlinearity in the series. At the most basic level, the presence of heavy tails, excess kurtosis, and non-normality are pointers to the possibility of the nonlinear nature of the series. However, we conduct a more formal test (BDS test) developed by Brock et al. (1996) to establish the presence of nonlinearity in the series. The BDS test is carried out on the residuals of each spillover series (overall and net) in the VAR (1) model that includes the EPU. In other words, the EPU index and each of the spillover series are captured in a VAR (1) model, after which the residuals of the latter are generated. Then, the BDS test is conducted on the generated residuals (see Balcilar et al., 2015; Balcilar et al., 2018a, b for a similar approach). The BDS test results in Table 4 show strong evidence of a nonlinear relationship between economic policy uncertainty and all the spillover series as the null hypothesis of serial dependence is resoundingly rejected across all dimensions. These results imply that there is more to what the linear Granger-causality test reveals, it likely could have suffered from the problem of misspecification.

Having detected strong evidence of a nonlinear relationship in the relationship between EPU and the connectedness among the assets, we turn to the results of the quantiles-based causality test. In order not to miss out on any important information, the quantiles-based causality analysis is conducted in both the conditional-mean and conditional-variance.

In sharp contrast to the results of the linear causality test, Table 5 which reports the nonlinear results for the conditional-mean and conditional-variance shows strong evidence of the rejection of the null hypothesis of no causality. The causal evidence is most significant at the lower quantiles, with some reaching the median region. However, the causality becomes weak at the extreme quantiles, suggesting that the effect of EPU on the connectedness among the markets is sensitive to the degree of the performance of the foreign exchange and oil markets. When the markets are performing at their peak, EPU appears to be weak in affecting their interactions.

In summary, our results reveal three facts: (i) there is strong connectedness between the REITs and currency markets; (ii) nonlinearity is a crucial factor to be put into consideration when examining the role of EPU in affecting the interactions between REITs and exchange rate markets; (iii) the connectedness among these markets are primarily driven by EPU, although the causal effect appears to be stronger around the lower and middle quantiles in most cases. In these scenarios, our results confirm those of Albulescu et al. (2019) who reveal that commodity currencies and the oil market are dynamically connected, and policy-induced uncertainty is significant in driving this interaction. Fortunately, their nonlinear causality techniques are different from the one explored in this study, yet, the results do not differ. This indicates that the impact of EPU on the interactions among financial and currency markets is stable and 
Review of Economic Analysis 14 (2022) 121-141

strong. On the other hand, although their study is mainly on the impact of economic policy uncertainty on stock returns, Balcilar et al. (2015) use a similar technique as ours (quantilesbased causality test) to prove that the jettisoning nonlinearity in the predictability of financial variables (and their connectedness) with economic policy uncertainty may lead to unreliable results.

Table 4: Brock et al., (1996) BDS Independence Test

\begin{tabular}{|c|c|c|c|c|c|}
\hline \multirow[t]{2}{*}{ Spillovers } & \multicolumn{5}{|c|}{ Dimension } \\
\hline & 2 & 3 & 4 & 5 & 6 \\
\hline $\begin{array}{l}\text { Total } \\
\text { Spillovers }\end{array}$ & $\begin{array}{l}0.0827 \\
(0.000)\end{array}$ & $\begin{array}{l}0.1319 \\
(0.000)\end{array}$ & $\begin{array}{l}0.1498 \\
(0.000)\end{array}$ & $\begin{array}{l}0.1546 \\
(0.000)\end{array}$ & $\begin{array}{l}0.1495 \\
(0.000)\end{array}$ \\
\hline \multicolumn{6}{|c|}{ Net Spillovers } \\
\hline Australia & $\begin{array}{l}0.0686 \\
(0.000)\end{array}$ & $\begin{array}{l}0.1045 \\
(0.000)\end{array}$ & $\begin{array}{l}0.1210 \\
(0.000)\end{array}$ & $\begin{array}{l}0.1258 \\
(0.000)\end{array}$ & $\begin{array}{l}0.1236 \\
(0.000)\end{array}$ \\
\hline Belgium & $\begin{array}{l}0.0370 \\
(0.000)\end{array}$ & $\begin{array}{l}0.0574 \\
(0.000)\end{array}$ & $\begin{array}{l}0.0680 \\
(0.000)\end{array}$ & $\begin{array}{l}0.0691 \\
(0.000)\end{array}$ & $\begin{array}{l}0.0671 \\
(0.000)\end{array}$ \\
\hline Canada & $\begin{array}{l}0.0262 \\
(0.000)\end{array}$ & $\begin{array}{l}0.0437 \\
(0.000)\end{array}$ & $\begin{array}{l}0.0506 \\
(0.000)\end{array}$ & $\begin{array}{l}0.0528 \\
(0.000)\end{array}$ & $\begin{array}{l}0.0531 \\
(0.000)\end{array}$ \\
\hline France & $\begin{array}{l}0.0063 \\
(0.179)\end{array}$ & $\begin{array}{l}0.0165 \\
(0.027)\end{array}$ & $\begin{array}{l}0.0184 \\
(0.039)\end{array}$ & $\begin{array}{l}0.0193 \\
(0.038)\end{array}$ & $\begin{array}{l}0.0203 \\
(0.024)\end{array}$ \\
\hline Germany & $\begin{array}{l}0.0202 \\
(0.000)\end{array}$ & $\begin{array}{l}0.0171 \\
(0.049)\end{array}$ & $\begin{array}{l}0.0236 \\
(0.023)\end{array}$ & $\begin{array}{l}0.0275 \\
(0.011)\end{array}$ & $\begin{array}{l}0.0292 \\
(0.005)\end{array}$ \\
\hline Hong Kong & $\begin{array}{l}0.0139 \\
(0.007)\end{array}$ & $\begin{array}{l}0.0165 \\
(0.046)\end{array}$ & $\begin{array}{l}0.0237 \\
(0.016)\end{array}$ & $\begin{array}{l}0.0273 \\
(0.007)\end{array}$ & $\begin{array}{l}0.0257 \\
(0.009)\end{array}$ \\
\hline Japan & $\begin{array}{l}0.0200 \\
(0.004)\end{array}$ & $\begin{array}{l}0.0268 \\
(0.017)\end{array}$ & $\begin{array}{l}0.0236 \\
(0.078)\end{array}$ & $\begin{array}{l}0.0269 \\
(0.055)\end{array}$ & $\begin{array}{l}0.0306 \\
(0.024)\end{array}$ \\
\hline Malaysia & $\begin{array}{l}0.0203 \\
(0.000)\end{array}$ & $\begin{array}{l}0.0262 \\
(0.006)\end{array}$ & $\begin{array}{l}0.0283 \\
(0.013)\end{array}$ & $\begin{array}{l}0.0311 \\
(0.009)\end{array}$ & $\begin{array}{l}0.0289 \\
(0.012)\end{array}$ \\
\hline Netherlands & $\begin{array}{l}0.0177 \\
(0.010)\end{array}$ & $\begin{array}{l}0.0310 \\
(0.004)\end{array}$ & $\begin{array}{l}0.0251 \\
(0.056)\end{array}$ & $\begin{array}{l}0.0319 \\
(0.020)\end{array}$ & $\begin{array}{l}0.0313 \\
(0.019)\end{array}$ \\
\hline New Zealand & $\begin{array}{l}0.0215 \\
(0.000)\end{array}$ & $\begin{array}{l}0.0305 \\
(0.000)\end{array}$ & $\begin{array}{l}0.0350 \\
(0.001)\end{array}$ & $\begin{array}{l}0.0346 \\
(0.002)\end{array}$ & $\begin{array}{l}0.0338 \\
(0.002)\end{array}$ \\
\hline Singapore & $\begin{array}{l}0.0244 \\
(0.000)\end{array}$ & $\begin{array}{l}0.0327 \\
(0.005)\end{array}$ & $\begin{array}{l}0.0319 \\
(0.022)\end{array}$ & $\begin{array}{l}0.0290 \\
(0.048)\end{array}$ & $\begin{array}{l}0.0292 \\
(0.040)\end{array}$ \\
\hline South Africa & $\begin{array}{l}0.0386 \\
(0.000)\end{array}$ & $\begin{array}{l}0.0676 \\
(0.000)\end{array}$ & $\begin{array}{l}0.0824 \\
(0.000)\end{array}$ & $\begin{array}{l}0.0895 \\
(0.000)\end{array}$ & $\begin{array}{l}0.0847 \\
(0.000)\end{array}$ \\
\hline Turkey & $\begin{array}{l}0.0194 \\
(0.000)\end{array}$ & $\begin{array}{l}0.0309 \\
(0.000)\end{array}$ & $\begin{array}{l}0.0417 \\
(0.000)\end{array}$ & $\begin{array}{l}0.0389 \\
(0.000)\end{array}$ & $\begin{array}{l}0.0393 \\
(0.000)\end{array}$ \\
\hline $\begin{array}{l}\text { United } \\
\text { Kingdom }\end{array}$ & $\begin{array}{l}0.0187 \\
(0.000)\end{array}$ & $\begin{array}{l}0.0379 \\
(0.000)\end{array}$ & $\begin{array}{l}0.0468 \\
(0.000)\end{array}$ & $\begin{array}{l}0.0438 \\
(0.000)\end{array}$ & $\begin{array}{l}0.0369 \\
(0.000)\end{array}$ \\
\hline EPU & $\begin{array}{l}0.0598 \\
(0.000)\end{array}$ & $\begin{array}{l}0.0982 \\
(0.000)\end{array}$ & $\begin{array}{l}0.1223 \\
(0.000)\end{array}$ & $\begin{array}{l}0.1304 \\
(0.000)\end{array}$ & $\begin{array}{l}0.1314 \\
(0.000)\end{array}$ \\
\hline
\end{tabular}

Note: Values in the parenthesis represent the p-value of the BDS test statistic; null hypothesis of serial dependence at various dimensions 
RAHEEM, FASANYA, YUSUF Co-Movement between REITs and Exchange Rate

Table 5: Quantile-based (nonlinear) causality test results

\begin{tabular}{|c|c|c|c|c|c|c|c|c|c|}
\hline & 0.1 & 0.2 & 0.3 & 0.4 & 0.5 & 0.6 & 0.7 & 0.8 & 0.9 \\
\hline & \multicolumn{9}{|c|}{ Causality in the conditional mean } \\
\hline $\begin{array}{l}\text { Overall } \\
\text { Spillover }\end{array}$ & $3.1567^{*}$ & $2.1174 *$ & 1.8796 & 1.2015 & 1.3215 & 0.9892 & 0.7856 & 0.3542 & 0.1269 \\
\hline Australia & $4.5179 *$ & $2.5581^{*}$ & $2.1376^{*}$ & 1.7855 & 1.2016 & 1.0084 & 0.7863 & 0.5899 & 0.5011 \\
\hline Belgium & $3.1760^{*}$ & $2.1178^{*}$ & 1.7856 & 1.2355 & 1.3253 & 0.8962 & 0.7852 & 0.3452 & 0.1423 \\
\hline Canada & $2.5283^{*}$ & $2.1685^{*}$ & 1.5862 & 0.9833 & 0.6325 & 0.4832 & 0.5843 & 0.3201 & 0.1861 \\
\hline France & $2.5365^{*}$ & $2.5544 *$ & $1.9915^{*}$ & 1.2646 & 0.5875 & 0.8973 & 0.6532 & 0.4853 & 0.6320 \\
\hline Germany & $3.8605^{*}$ & $2.1583^{*}$ & 1.2565 & 1.20143 & 1.3265 & 0.8756 & 0.6530 & 0.4201 & 0.2156 \\
\hline Hong Kong & 1.4876 & 1.3215 & 1.1036 & 0.8653 & 0.5616 & 0.8756 & 0.7320 & 0.4320 & 0.1035 \\
\hline Japan & $3.5881 *$ & $2.5643^{*}$ & $2.0215^{*}$ & 1.7584 & 1.0015 & 0.4563 & 0.4232 & 0.3214 & 0.3285 \\
\hline Malaysia & $3.3032 *$ & $2.5607^{*}$ & $2.5716^{*}$ & $1.9878^{*}$ & 1.7896 & 1.0498 & 0.7866 & 0.3556 & 0.2148 \\
\hline Netherlands & 1.2559 & 1.326 & 1.0216 & 0.8556 & 0.7584 & 0.6201 & 0.3255 & 0.4746 & 0.5013 \\
\hline New Zealand & $2.4943 *$ & 1.8973 & 1.4863 & 1.3211 & 1.2571 & 1.1536 & 0.5966 & 0.4771 & 0.1874 \\
\hline Singapore & $2.3499 *$ & $2.0248^{*}$ & 1.2541 & 1.0023 & 0.7586 & 0.5210 & 0.5238 & 0.2587 & 0.1896 \\
\hline South Africa & $2.4590^{*}$ & $2.1729 *$ & 1.2473 & 1.3547 & 0.7698 & 0.4984 & 0.7473 & 0.4745 & 0.3215 \\
\hline Turkey & $2.5366^{*}$ & 1.9015 & 1.2046 & 1.2533 & 1.2589 & 0.5211 & 0.4021 & 0.2320 & 0.1258 \\
\hline \multirow[t]{2}{*}{$\begin{array}{l}\text { United } \\
\text { Kingdom }\end{array}$} & $2.7591 *$ & $2.7031^{*}$ & $2.2478^{*}$ & 1.7569 & 1.2498 & 0.8786 & 0.4873 & 0.1479 & 0.093 \\
\hline & \multicolumn{8}{|c|}{ Causality in the conditional variance } & \\
\hline $\begin{array}{l}\text { Overall } \\
\text { Spillover }\end{array}$ & $3.1570^{*}$ & 1.8756 & 1.5695 & 1.4632 & 1.3621 & 0.8995 & 0.6854 & 0.2243 & 0.3421 \\
\hline Australia & $3.1567 *$ & 1.8786 & 1.7856 & 1.8032 & 1.3963 & 1.0244 & 0.8697 & 0.4011 & 0.3215 \\
\hline Belgium & $2.1570^{*}$ & 1.7856 & 1.6587 & 1.2541 & 1.3246 & 0.7430 & 0.4323 & 0.2352 & 0.3107 \\
\hline Canada & $2.5684^{*}$ & 1.4783 & 1.4520 & 0.9987 & 0.7853 & 0.9573 & 0.6325 & 0.3587 & 0.0983 \\
\hline France & $4.4917^{*}$ & $4.3310^{*}$ & $2.8736^{*}$ & $1.9682^{*}$ & 1.4856 & 1.2452 & 0.5783 & 0.3520 & 0.1365 \\
\hline Germany & $2.8905^{*}$ & $2.8655^{*}$ & 1.2038 & 0.9899 & 0.8626 & 0.5862 & 0.6962 & 0.2413 & 0.1260 \\
\hline Hong Kong & $2.5875^{*}$ & $2.0160^{*}$ & 1.2548 & 0.8730 & 0.2062 & 0.8460 & 0.7651 & 0.5423 & 0.5483 \\
\hline Japan & $3.4802 *$ & $2.0422 *$ & 1.7459 & 1.2135 & 1.0214 & 0.7851 & 0.4136 & 0.2148 & 0.3576 \\
\hline Malaysia & $6.2442 *$ & 2.8884* & $2.7629 *$ & $2.008 *$ & 1.8795 & 1.6548 & 0.8743 & 0.4586 & 0.5477 \\
\hline Netherlands & 1.2158 & 1.3255 & 1.4203 & 1.0211 & 0.9631 & 0.7568 & 0.5122 & 0.3220 & 0.2308 \\
\hline New Zealand & $2.7983^{*}$ & $2.0145^{*}$ & 1.3584 & 0.3211 & 1.2896 & 1.2963 & 0.7893 & 0.6523 & 0.5472 \\
\hline Singapore & 1.7469 & 1.7584 & 1.3252 & 0.8963 & 0.7586 & 0.7432 & 0.5428 & 0.2511 & 0.1032 \\
\hline South Africa & $4.6087 *$ & $2.5234^{*}$ & 1.7587 & 1.0015 & 0.8746 & 0.5741 & 0.6896 & 0.3985 & 0.2014 \\
\hline Turkey & $3.1990 *$ & 1.8723 & 1.8865 & 1.1542 & 0.7587 & 0.9968 & 0.7413 & 0.2875 & 0.1735 \\
\hline $\begin{array}{l}\text { United } \\
\text { Kingdom }\end{array}$ & $4.8569^{*}$ & $2.4746^{*}$ & $2.0147^{*}$ & 1.1463 & 0.8596 & 0.7832 & 0.5413 & 0.1436 & 0.2102 \\
\hline
\end{tabular}

Source: Authors' computation

Note: the null hypothesis is that EPU does not nonlinearly cause Net Spillover and * implies a level of statistical significance at 5\%. 


\section{Conclusion}

The REITs market has attracted a lot of interest among the academic, policymakers, and market participants. REITs have been linked to several macroeconomic and financial variables. In the context of this study, we argue that first, there is a high comovement between REITs and exchange rates. Next to this, it is hypothesised that the uncertainty in government economic policies will nonlinearly affect the comovement in the REITs-exchange rate nexus. The objective of the study is to examine the role of EPU in the comovement/spillover between REITs and currency markets. This objective is pursued in two phases. In the first phase, we used Diebold and Yilmaz (2012) to examine the comovement between REITs and exchange rate. We subject the results of the first phase to a non-parametric causality-in-quantile test with economic policy uncertainty (EPU).

Results show that there is strong connectedness between the REITs and currency markets. Essentially, the REITs of the Netherlands, France, and United Kingdom are the largest shock receivers from all other assets respectively, while Malaysia, Japan, and Hong Kong REITs are the least receiver of shocks in the sample. Sequentially, Australia, Belgium, Canada, and New Zealand are the major contributors of shock in the market. Results of the second phase indicate that EPU is a major driver of the connectedness between the REITs and currency markets. Furthermore, the relationship between EPU and the markets is stronger at the lower-middle quantiles.

Based on the foregoing, there are two major discerning policy implications. First, the influence of the volatility of the US Dollar (USD) cannot be ignored. The volatility of the USD will transmit into the REITs market. As such, policymakers in the REITs domiciled countries should formulate policies in line with the movements of the USD. Expatiating further, foreign currency policies should not be made in isolation of the USD trends. Second, uncertainty, in the form of economic policy affects the REITs-currency market nexus. Hence, there is the need to account for the important role of EPU. Succinctly, the broad policy implication of our results is that participants in the REIT's market should not ignore the influence of activities in the US markets.

In comparison to other financial markets, the REITs literature is in its embryonic state. Hence, there are many avenues for future research. While this study has pushed the frontier of knowledge on REITs, it can also serve as a benchmark for future studies. Thus, our study could be improved in the following ways. One, there are quite a couple of measures of uncertainty. It has been documented in related literature that these measures have heterogeneous impacts/effects on financial series. Succeeding studies could examine if our results are sensitive to the measures of uncertainty. Two, we only considered a form of uncertainty, quantile regression. Future studies could explore other channels of non-linearity. 
RAHEEM, FASANYA, YUSUF Co-Movement between REITs and Exchange Rate

\section{References}

Akimov, A., Stevenson, S., \& Zagonov, M. (2015). Public real estate and the term structure of interest rates: a cross-country study. The Journal of Real Estate Finance and Economics, 51(4), 503-540.

Albulescu, C. T., Bouri, E., Tiwari, A.K. and Roubaud, D. (2020). Quantile causality between banking stock and real estate securities returns in the US. The Quarterly Review of Economics and Finance, https://doi.org/10.1016/j.qref.2020.03.005

Amano, R., van Norden, S. (1998). Exchange rates and Oil Prices. Review of International Economics, 6, 683-694

Baker, S.R., Bloom, N. and Davis, S.J. (2016). Measuring Economic Policy Uncertainty. The Quarterly Journal of Economics, 131(4), 1593-1636

Balcilar, M., Gupta, R., Pierdzioch, C., and Wohar, M.E. (2018a). Terror Attacks and Stock Market Fluctuations: Evidence Based on a Nonparametric Causality-in-Quantiles Test for the G7 Countries. European Journal of Finance, 24(4), 333-346.

Balcilar, M., Gupta, R., Kim, J. W., \& Kyei, C. (2018b). The role of economic policy uncertainties in predicting stock returns and their volatility for Hong Kong, Malaysia and South Korea. International Review of Economics and Finance, Vol. 59, pp. 150-163

Balcilar, M., Gupta, R., Miller, S.M., (2015). Regime switching model of US crude oil and stock market prices: 1859 to 2013. Energy Economics 49, 317-327.

Brock, W., Dechert, D., Scheinkman, J., and LeBaron, B. (1996). A test for independence based on the correlation dimension. Econometric Reviews, 15 197-235

Caporin, M., Gupta, R. and Ravazzolo, F. (2019). Contagion between Real Estate and Financial Markets: A Bayesian Quantile-on-Quantile Approach. BEMPS - Bozen Economics \& Management Paper Series BEMPS61, Faculty of Economics and Management at the Free University of Bozen.

Chang, G-D., and Chen, C-S. (2014). Evidence of contagion in global REITs investment. International Review of Economics and Finance, 31, 148-158.

Chang, G-D., and Chen, P-C (2016). Evidence of cross-asset contagion in U.S. markets. Economic Modelling, 58, 219-226

Chang, K-L. (2011). The nonlinear effects of expected and unexpected components of monetary policy on the dynamics of REIT returns. Economic Modelling, 28, 911-920

Cheok, S.M., Sing, T.F., Tsai, I-C. (2011). Diversification as a Value-Adding Strategy for Asian REITs: A Myth or Reality? International Real Estate Review, 14(2), 184-207

Coen, A., and Lecomte, P. (2014) Chapter 4: Another Look at Asian REITs Performance after the Global Financial Crisis. Handbook of Asian Finance, 69-94

Darby, M.R. (1982). The price of oil, world inflation and recession. American Economic Review, 72, 738-751. 
Devaney, M. (2012). Financial crisis, REIT short-sell restrictions and event induced volatility. The Quarterly Review of Economics and Finance 52(2), 219-226

Diebold, F. and Yilmaz, K. (2012). Better to give than to receive: Predictive directional measurement of volatility spillovers. International Journal of Forecasting, 28(1), 57-66,

Ertugrul, M., Sezer, O. and Sirmans, C.F. (2008). Financial leverage, CEO compensation, and corporate hedging: Evidence from real estate investment trusts. Journal of Real Estate Finance and Economics, 36, 53-80

Gerlach, R., Obavdin, I., and Zurbruegg, R. (2015). The impact of leverage on the idiosyncratic risk and return relationship of REITs around the financial crisis. International Review of Economics and Finance, 38, 207-219

Golub, S. (1983). Oil prices and exchange rate. Economic Journal, 93, 576-593

Gorea, D. and Radev, D. (2014). The euro area sovereign debt crisis: can contagion spread from the periphery to the core? International Review of Economics and Finance, 30, 78-100

Hoesli, M. and Reka, K., 2013. Volatility Spillovers, Comovements and Contagion in Securitized Real Estate Markets. Journal of Real Estate Finance and Economics, 47, 1-35.

Hsieh, C., and Peterson, J.D. (2000). Book Assets, Real Estate, and Returns on Common Stock. Journal of Real Estate Finance and Economics, 21, 221-233

Jeong, K., W. K. Härdle, and S. Song. (2012). A Consistent Nonparametric Test for Causality in Quantile. Econometric Theory, 28: 861-887.

Kola, K., and Kodongo, O. (2017). Macroeconomic risks and REITs returns: A comparative analysis. Research in International Business and Finance, Elsevier, vol. 42(C), pages 12281243.

Lee, C-C., Chien. M-S., Lin, T.C. (2012). Dynamic modelling of real estate investment trusts and stock markets. Economic Modelling, 29(2), 395-407

Lee, C-C., Lee, C-F., and Lee, C.-Chuan (2014). Asymmetric dynamics in REIT prices: Further evidence based on quantile regression analysis. Economic Modelling, 29-37

Li, J., \& Lei, L. (2011). Determinants and information of REIT pricing. Applied Economics Letters, 18, 1501-1505.

Lin, C., Rahman, H., and Yung, K. (2009). Investor Sentiment and REIT Returns. The Journal of Real Estate Finance and Economics, 39(4), 450-471

Liow, K. H., and Newell, G. (2016). Real estate global beta and spillovers: An international study. Economic Modelling, 59, 297-313.

Marfatia, H.A., Gupta, R., and Cakan, E. (2017). The international REIT's time-varying response to the U.S. monetary policy and macroeconomic surprises. North American Journal of Economics and Finance, 42, 640-653.

Morales, L. and Andreosso-O'Callaghan, B. (2014). The global financial crisis: world market or regional contagion effects? International Review of Economics and Finance, 29, 108-131 
RAHEEM, FASANYA, YUSUF Co-Movement between REITs and Exchange Rate

Nazlioglu, S., Gormus, A.N. and Soytas, U. (2016). Oil prices and real estate investment trusts (REITs): Gradual-shift causality and volatility transmission analysis. Energy Economics, $60,168-175$

Ngo, T. (2017). Exchange rate exposure of REITs. The Quarterly Review of Economics and Finance, 64, 249-258

Nishiyama, Y., Hitomi, K., Kawasaki, Y., Jeong, K., 2011. A consistent nonparametric test for nonlinear causality - Specification in time series regression. Journal of Econometrics, 165, 112-127.

Payne, J. (2003). Shocks to Macroeconomic State Variables and the Risk Premium of REITs. Applied Economics Letters, 10(11), pp.671-677.

Poole, W. (1970). Optimal Choice of Monetary Policy Instruments in a Simple Stochastic Macro Model. Quarterly Journal of Economics, 88, 197-216

Schindler, F. (2011). Long-term benefits from investing in international securitised real estate. International Real Estate Review, 14(1), 27-60.

Tsai, M. and Chiang, S. (2013).The asymmetric price adjustment between REIT and stock markets in Asia-Pacific markets. Economic Modelling, Elsevier, vol. 32(C), pages 91-99.

Xiao, Z., Lin, Z., and Li, S. (2014). Expected return, time-varying risk, and hedging demand in the US REITs market. Journal of Management Analysis, 1(2), 78-98

Yong, J., \& Singh, A. (2015). Interest rate risk of Australian REITS: A panel analysis. Pacific Rim Property Research Journal, 21(1), 77-88. 